\title{
Do hydrolysed infant formulas reduce the risk of allergic disease?
}

\author{
(9) $(1)(9)$ OPEN ACCESS \\ With no supporting evidence, guidelines should stop recommending these products
}

\section{Caroline Jane Lodge research fellow, Adrian John Lowe senior research fellow, Shyamali Chandrika Dharmage professor}

Allergy and Lung Health Unit, Centre for Epidemiology and Biostatistics, Melbourne School of Population and Global Health, University of Melbourne, Vic 3010, Australia

Breast feeding is the first and most important feeding exposure, and it facilitates the establishment of the microbiome of the infant gut by providing breast milk microbiota, immunomodulatory factors, and oligosaccharides. ${ }^{1}$ While there is insufficient evidence to state that breast feeding prevents allergies, ${ }^{2}$ it seems to prevent a range of other diseases and is universally encouraged. ${ }^{3}$ Guidelines advocate exclusive breast feeding for four to six months (with WHO recommending six months) and complementary feeding for at least one to two years. Breast milk substitutes are used on cessation of established breast feeding or earlier if mothers cannot breast feed. The quality of these substitutes, and their ability to play a role in optimal health and disease prevention, are of intense interest, both to the public and also to commercial entities keen to produce an acceptable and safe alternative to breast milk.

A linked systematic review by Boyle and colleagues (doi:10. 1136/bmj.i974) investigates whether hydrolysed cows' milk formulas can prevent allergic or autoimmune disease. ${ }^{4}$ The term "hydrolysed" is used to describe proteins that have been broken down by enzymes into smaller, less allergenic, peptide

fragments. Infant feeding guidelines in Europe, America, and Australasia ${ }^{5-7}$ support the use of hydrolysed formulas in place of standard cows' milk formula if the infant is not breast fed for the prevention of allergic disease in children at increased risk, despite ongoing debate as to whether there is sufficient evidence to support this recommendation.

Boyle and colleagues conducted a comprehensive review using rigorous methods. It supersedes the previous and now outdated Cochrane review by Osborn and Sinn on this topic. ${ }^{8}$ Osborne and Sinn found "limited evidence that prolonged feeding with a hydrolysed formula compared to a cow's milk formula reduces infant and childhood allergy and infant CMA [cows' milk allergy]." In contrast, by including the most recent evidence and through a critical appraisal of the literature, Boyle and colleagues found "no consistent evidence that partially or extensively hydrolysed formulas reduce risk of allergic or autoimmune outcomes" and highlighted the low quality of evidence. On the basis of these findings, they ask for changes to current infant feeding guidelines that recommend the use of these formulas.

A major strength of the current review is its assessment of all included studies for quality, along with an overall assessment of the quality of evidence from each meta-analysis by using the Grades of Recommendation, Assessment, Development and Evaluation (GRADE) criteria. ${ }^{9}$ The GRADE criteria provide a framework for a systematic approach to both rating the quality and strength of the evidence derived from systematic reviews and developing recommendations from this evidence. Boyle and colleagues emphasise that many of the trials investigating the effect of hydrolysed formulas on risk of allergic disease have a high or unclear risk of bias because of conflicts of interest related to sponsorship from industry. Given the commercially sensitive nature of this topic, it is reassuring that, when it was possible to investigate, they did not find evidence that these conflicts of interest influenced the reported associations for individual outcomes. With increasing and necessary involvement of industry in medical science it is imperative that we take steps to ensure transparency and prevent commercial priorities from influencing published results.

While experts might recognise the lack of evidence for the effectiveness of hydrolysed formulas in prevention of allergies, it seems that these formulas are currently recommended in the hope that they might prevent allergic disease and on the basis that they are unlikely to do any harm. The most undesirable consequence of this approach is that it can unwittingly undermine efforts to promote breast feeding. We know that formula feeding, whether the formula is hydrolysed or not, cannot replicate the complex and adaptive constituents of breast milk and the benefits of breast feeding for mothers or babies. ${ }^{3}$ Advice from medical personnel and mothers' perceptions of breast feeding can be altered by advocacy for particular types of formula within infant feeding guidelines. Secondly, endorsing 
hydrolysed formulas as an effective means to prevent allergies undermines attempts to conduct further more robust and definitive research on this issue. Finally, accepting that a particular formula prevents allergy based on poor quality evidence hinders further efforts by formula producers to improve their products.

It is now time for this evidence to be used for updating and clarifying current recommendations and guidelines. Furthermore, we encourage industry to pursue development of effective allergy reducing infant formulas and call for further transparent and well conducted studies in this area.

Competing interests: We have read and understood the BMJ Group policy on declaration of interests and declare the following interests: none.

Provenance and peer review: Commissioned; not externally peer reviewed.

1 Bode L, McGuire M, Rodriguez JM, et al. It's alive: microbes and cells in human milk and their potential benefits to mother and infant. Adv Nutr 2014;5:571-3. doi:10.3945/an.114. 006643. 25469400.
2 Lodge CJ, Tan DJ, Lau MX, et al. Breastfeeding and asthma and allergies: a systematic review and meta-analysis. Acta Paediatr 2015;104:38-53.26192405.

3 Victora CG, Bahl R, Barros AJD, et al. Lancet Breastfeeding Series Group. Breastfeeding in the 21st century: epidemiology, mechanisms, and lifelong effect. Lancet 2016;387:475-90. doi:10.1016/S0140-6736(15)01024-7. 26869575.

4 Boyle RJ, lerodiakonou D, Khan T, et al. Hydrolysed formula and risk of allergic or autoimmune disease: systematic review and meta-analysis. BMJ 2016;351:i974.

5 Australasian Society of Clinical Immunology and Allergy. ASCIA Infant feeding advice. ASCIA, 2010. http://www.allergy.org.au/health-professionals/papers/ascia-infant-feedingadvice

6 Muraro A, Halken S, Arshad SH, et al. EAACI Food Allergy and Anaphylaxis Guidelines Group. EAACl food allergy and anaphylaxis guidelines. Primary prevention of food allergy. Allergy 2014;69:590-601. doi:10.1111/all.12398. 24697491.

7 Fleischer DM, Spergel JM, Assa'ad AH, Pongracic JA. Primary prevention of allergic disease through nutritional interventions. J Allergy Clin Immunol Pract 2013;1:29-36. doi: 10.1016/j.jaip.2012.09.003. 24229819.

8 Osborn DA, Sinn J. Formulas containing hydrolysed protein for prevention of allergy and food intolerance in infants. Cochrane Database Syst Rev 2006;4:CD003664.17054180.

9 Guyatt GH, Oxman AD, Schünemann HJ, Tugwell P, Knottnerus A. GRADE guidelines: a new series of articles in the Journal of Clinical Epidemiology. J Clin Epidemio 2011;64:380-2. doi:10.1016/j.jclinepi.2010.09.011. 21185693.

Published by the BMJ Publishing Group Limited. For permission to use (where not already granted under a licence) please go to http://group.bmj.com/group/rights-licensing/ permissions

This is an Open Access article distributed in accordance with the Creative Commons Attribution Non Commercial (CC BY-NC 3.0) license, which permits others to distribute, remix, adapt, build upon this work non-commercially, and license their derivative works on different terms, provided the original work is properly cited and the use is non-commercial. See: http://creativecommons.org/licenses/by-nc/3.0/. 